\title{
Dampak Earnings Management dalam Hubungan Kinerja dengan Cost of Debt \\ (Studi Pada Perusahaan Manufaktur di Bursa Efek Indonesia)
}

\author{
Muhamad Safiq \\ safiq2006@gmail.com \\ Sekolah Tinggi Ilmu Ekonomi Indonesia, Jakarta, Indonesia \\ Andi Ina Yustina \\ a.inayustina@president.ac.id \\ Accounting Study Program, Faculty of Business \\ Universitas Presiden, Cikarang, Indonesia \\ Aeniyatul Muhaqiyah \\ Sekolah Tinggi Ilmu Ekonomi Indonesia, Jakarta, Indonesia
}

\section{Intisari}

Penelitian ini bertujuan untuk menguji dampak earnings management dalam hubungan antara kinerja perusahaan dan cost of debt di Bursa Efek Indonesia (BEI). Dalam penelitian ini, kinerja perusahaan yang diproksi dengan rasio profitabilitas (return on equity), earnings management yang diukur dengan discretionary accrual, serta cost of debt diukur dengan rasio biaya bunga dibagi dengan rerata total utang. Sampel penelitian ini adalah perusahaan manufaktur yang terdapat di Bursa Efek Indonesia (BEI) tahun 2013 sampai dengan tahun 2015 yang diambil dengan menggunakan metode purposive sampling, menghasilkan 30 perusahaan manufaktur dan 90 observasi. Sehingga, data yang diperoleh berupa data panel. Selanjutnya, hasil observasi atau data yang diperoleh diproses dengan pengolah data Eviews. Hasil penelitian menunjukkan bahwa pertama, kinerja perusahaan berpengaruh negatif terhadap cost of debt; dan kedua, earnings management memoderasi (memperlemah) hubungan antara kinerja perusahaan dengan cost of debt. Untuk memperkuat hasil tersebut, penelitian selanjutnya dapat menambahkan jumlah perusahaan yang melalui periode yang digunakan dan industri yang berbeda.

Kata kunci: kinerja perusahaan, earnings management, dan cost of debt 


\title{
The Impacts of Earnings Management in the Performance Relationship and the Cost of Debt
}

\section{(A Study on Manufacturing Companies in Indonesia Stock Exchange)}

\author{
Muhamad Safiq \\ safiq2006@gmail.com \\ Sekolah Tinggi Ilmu Ekonomi Indonesia, Jakarta, Indonesia \\ Andi Ina Yustina \\ a.inayustina@president.ac.id \\ Accounting Study Program, Faculty of Business \\ Universitas Presiden, Cikarang, Indonesia \\ Aeniyatul Muhaqiyah \\ Sekolah Tinggi Ilmu Ekonomi Indonesia, Jakarta, Indonesia
}

\begin{abstract}
This study aims to analyse the profit management in relation with corporate performance and debt costs in the Indonesia Stock Exchange (BEI). In this study, firm performance is proxyed with profitability ratios (return on equity), earnings management used with discretionary accrual, and debt cost is measured by ratio of interest cost divided by total debt. The samples of this research are companies listed on the Indonesia Stock Exchange (BEI) from 2013 to 2015. It uses purposive sampling technique by which yields 30 manufacturing companies with $90 \%$ rate. Thus, the data obtained are panels data. Furthermore, these data are processed using Eviews. The results show firstly the firm's performance has negative impact on the cost of debt. Secondly, earnings management moderates (weakens) the relationship between the firm's performance and the cost of debt. From these results, further research may add the number of companies samples using different periods and industries.
\end{abstract}

Keywords: company performance, earnings management, and debt costs 


\section{PENDAHULUAN}

Laporan keuangan merupakan salah satu informasi bagi investor dan kreditor dalam membuat keputusan. Sesuai dengan tujuan Standar Akuntansi Keuangan (SAK) No. 1, penyajian laporan keuangan bertujuan untuk menyediakan informasi-informasi yang terkait dengan posisi keuangan, kinerja, serta perubahan ekuitas perusahaan. Berdasarkan informasi tersebut, kreditor dapat memonitor perkembangan kinerja perusahaan. Bagi kreditor, informasi tersebut dapat digunakan untuk menilai prospek perusahaaan di masa mendatang. Bila laporan keuangan mengindikasikan kinerja perusahaan yang baik, maka persepsi kreditor terhadap perusahaan tersebut juga baik. Hal itu dikarenakan kemampuan perusahaan dalam memenuhi kewajiban juga meningkat, sehingga kondisi tersebut dapat digunakan kreditor untuk mengapresiasi secara positif melalui tingkat suku bunga yang dibebankan. Sebaliknya, bila kinerja perusahaan buruk yang terindikasi dari laba perusahaan yang menurun maka kreditor juga akan memberikan apresiasi, tetapi apresiasiasinya negatif yang tercerimin dengan peningkatan suku bunga pinjaman yang diberikan dengan alasan untuk meng-cover risiko.

Ketika perusahaan menggunakan kebijakan utang dalam pendanaan perusahaan maka perusahaan yang memiliki risiko yang rendah akan dibebani dengan biaya hutang (cost of debt) yang rendah pula, begitu sebaliknya. Risiko merupakan salah satu faktor yang dapat menyebabkan biaya hutang (cost of debt) perusahaan meningkat. Jika perusahaan tidak dapat menunjukan kinerja yang baik, misalnya laba tidak sesuai ekspektasi penggunanya, maka manajemen akan berusaha untuk memenuhi ekspektasi pengguna tersebut. Melalui fleksibilitas yang dimilikinya, manajemen dapat memilih kebijakan akuntansi yang dapat mempengaruhi kinerja perusahaan. Sebagaimana yang dijelaskan dalam Standar Akuntansi Keuangan (SAK), maka manajemen dapat memillih kebijakan akuntansi tertentu sesuai dengan keinginannya tanpa melanggar standar tersebut. Upaya manajer untuk memilih metode akuntansi tertentu yang dapat menghasilkan informasi laba yang diinginkan (lebih baik) dikatakan sebagai manajemen laba (earnings management). Dengan demikian, earnings management merupakan intervensi manajemen dengan sengaja dalam proses penentuan laba, biasanya untuk memenuhi tujuan pribadi (Schipper dalam Subramanyam \& Wild, 2014).

Selanjutnya, earnings management yang dilakukan manajemen dapat dilihat dalam dua perspektif. Pertama, earnings management yang dilakukan perusahaan yang bersifat efisien (meningkatkan keinformatifan laba dalam mengkomunikasikan informasi privat). Kedua, earnings management yang bersifat oportunistik, yaitu manajemen yang melaporkan laba secara oportunis untuk memaksimumkan kepentingan pribadinya (Scott, 2015). Pengelolaan laba yang bersifat oportunis atau untuk tujuan pribadi, informasi yang disampaikan terkadang tidak menunjukan nilai perusahaan yang sebenarnya karena tidak sesuai dengan kondisi perusahaan yang nyata. Hal tersebut dilakukan untuk dapat meminimalkan biaya hutang (cost of debt) yang harus ditanggung perusahaan.

Pada umumnya, earnings management dilakukan untuk memenuhi kepentingan pribadinya (manajemen) dibandingkan untuk mewujudkan kepentingan semua stakeholder. Misalnya, manajer melakukan earnings management yang meningkatkan laba yang dilaporkan dengan tujuan untuk mendapat reward (bonus) yang besar (Healy, 1984). Sedangkan, berkaitan dengan kontrak utang, laba yang tinggi akan diapresiasi positif oleh kreditor karena dianggap memiliki kemampuan untuk melunasi hutang-hutang tepat waktu. Selain itu, kinerja yang baik dapat meminimalkan kemungkinan terjadinya pelanggaran perjanjian hutang. Sebaliknya, kondisi yang kurang baik dapat mengakibatkan perusahaan harus mengeluarkan cost of debt yang lebih tinggi dalam melunasi kewajibannya.

Berdasarkan uraian tersebut dapat diketahui bahwa perusahaan dengan kinerja yang baik 
kecil kemungkinan melakukan manajemen laba (Pratiwi, 2015). Berbeda dengan tingkat kinerja perusahaan yang buruk, agar mendapat respon yang baik oleh kreditor manajemen perusahaan cenderung melakukan earnings management untuk menghindari biaya hutang (cost of debt) dalam pendanaan kembali yang semakin tinggi. Hal ini mendukung penelitian Prevost et al., (2008) yang membuktikan adanya hubungan positif antara manajemen laba dengan cost of debt. Pasar utang dapat diobservasi melalui upaya manajer dalam memanfaatkan peluang untuk mengubah persepsi dari laba perusahaan, dan adanya hubungan positif antara rasio hutang dan discreationary acrual (Nikoomaram, et al., 2016).

\section{Perumusan Masalah}

Berdasarkan penjelasan yang telah disampaikan sebelumnya, maka peneliti dapat merumuskan masalah penelitian yang akan diuji dalam penelitian adalah sebagai berikut. Pertama, apakah kinerja perusahaan mempengaruhi positif terhadap cost of debt? Kedua, apakah earnings management memoderasi (memperlemah) pengaruh positif kinerja perusahaan terhadap cost of debt?

\section{TINJAUAN PUSTAKA}

Beberapa hasil penelitian sebelumnya telah mendokumentasikan manfaat keinformativan laba dalam masalah pengontrakan. Triningtyas dan Siregar (2014) melaporkan adanya pengaruh kualitas akrual terhadap biaya utang dan biaya ekuitas. Dengan menggunakan model yang dikembangkan Francis et al., (2005) untuk menentukan kualitas akrual mereka menunjukkan bahwa kualitas akrual innate, dan kualitas akrual diskresioner tidak berpengaruh terhadap biaya utang. Juga ditemukan bahwa tidak ada perbedaan pengaruh antara kualitas akrual innate dan kualitas akrual diskresioner terhadap biaya utang. Dalam penelitian tersebut juga mengungkapan adanya kelemahan yaitu hanya menggunakan satu model kualitas akrual yaitu Francis et al., (2005).

Kemudian, Nikoomaram et al., (2016) juga melaporkan hasil penelitian yang berkaitan antara earnings management dan struktur modal. Dengan menggunakan perbandingan Jones Model dan Modified Jones Model, mereka mendokumentasikan adanya hubungan positif antara rasio hutang dan akrual diskresioner. Selain itu, juga terdapat hubungan negatif antara return on asset (ROA) dan rasio utang, serta return on equity berhubungan positif dengan rasio hutang.

Dewi dan Priyadi (2016) melaporkan adanya pengaruh kinerja keuangan terhadap earnings management. Kinerja keuangan diproksikan dengan rasio leverage (debt ratio) dan rasio profitabilitas (return on asset), sedangkan earnings management diproksikan dengan discretionary accrual. Hasil penelitiannya menunjukkan bahwa leverage berpengaruh negatif terhadap earnings management, rasio leverage yang tinggi mendorong manajemen perusahaan untuk menurunkan perilaku earnings managementnya. Amperaningrum dan Sari (2013) juga melaporkan adanya pengaruh kinerja keuangan terhadap manajemen laba. Kinerja keuangan diukur dengan menggunakan Capital Adequacy Ratio (CAR), sedangkan manajemen laba diproksikan dengan model Modified Jones Model.

Selanjutnya, Febrininta dan Siregar (2014) melaporkan hasil penelitian mengenai manajemen laba melalui akrual, akitivitas riil, dan biaya modal. Metode yang digunakan dalam pengukuran manajemen laba terhadap biaya utang yaitu model Kaplan dan Urwitz yaitu diukur dengan rasio dari biaya bunga terhadap rerata total utang. Sedangkan pengukuran manajemen laba riil terhadap biaya ekuitas diukur dengan Model Kim dan Shon (2013) yaitu biaya ekuitas diestimasi dengan menggunakan metode CAPM (Capital Market Pricing Model). Hasil penelitiannya menunjukkan bahwa manajemen laba akrual terbukti tidak mempunyai pengaruh signifikan terhadap biaya utang. Manajemen laba riil secara 
agregat juga terbukti tidak berpengaruh signifikan terhadap biaya utang dan manajemen laba akrual terbukti tidak mempunyai pengaruh terhadap biaya ekuitas. Manajemen laba riil juga terbukti tidak berpengaruh terhadap biaya ekuitas.

Lebih lanjut, Ge dan Kim (2013) melaporkan hasil penelitian mengenai manajemen laba riil dan biaya pinjaman baru perusahaan. Mereka mendokumentasikan bahwa manajemen laba riil tidak berpengaruh signifikan terhadap bond ratings, kemudian perusahaan yang memiliki produksi berlebih (overproduction) credit ratings menurun. Selanjutnya manipulasi penjualan dan overproduction memiliki pengaruh dengan bond yield spreads yang lebih tinggi. Kelemahan penelitian ini yaitu penelitian ini hanya terbatas pada perusahaan dengan pinjaman baru, tidak menyediakan gambaran bagaimana manajemen laba riil mempengaruhi biaya utang public dan private.

Demirkan et al., (2011) mengembangkan penelitian sebelumnya yang berkaitan dengan discretionary accruals quality, cost of capital, and diversification. Mereka melaporkan bahwa the quality of discretionary accruals lebih rendah pada perusahaan multi segmen daripada perusahaan single segment, kemudian perusahaan multi segmen memiliki biaya modal yang lebih tinggi daripada perusahaan single segment untuk level yang sama dari discretionary accruals quality. Sedangkan, Admadianto (2015) melaporkan tidak adanya hubungan antara manajemen laba dengan cost of capital. Jadi ketika para manajer melakukan tindakan manajemen laba dengan berbagai teknik yang dilakukan dengan tujuan mencapai tingkat laba yang diinginkan perusahaan agar investor suka, maka tindakan itu tidak akan mempengaruhi biaya modal.

\section{Teori Keagenan (Agency Theory)}

Dalam teori keagenan (agency theory), Jensen dan Meckling (1976) menjelaskan bahwa hubungan agensi terjadi ketika satu orang atau lebih (principal) mempekerjakan orang lain (agent) untuk memberikan suatu jasa dan kemudian mendelegasikan wewenang pengambilan keputusan kepada agent tersebut. Dijelaskan dalam Jensen dan Meckling (1976), bahwa masalah keagenan dapat terjadi dalam dua bentuk hubungan, yaitu: (1)antara pemegang saham dan manajer, dan (2)antara pemegang saham dan kreditor.

Pertama, konflik antara pemegang saham (principal) dan manajer (agent). Principal dan agent memiliki kepentingan masing-masing. Pemegang saham sebagai principal diasumsikan hanya tertarik kepada peningkatan kinerja keuangan perusahaan berupa tingkat pengembalian yang tinggi atas investasi mereka. Sedangkan para agent diasumsikan akan menerima apresiasi dari principal berupa kompensasi keuangan dan syarat-syarat yang menyertai dalam hubungan tersebut. Perbedaan kepentingan ini menyebabkan conflict of interest diantara kedua pihak, dimana agent berada pada posisi yang memiliki informasi yang lebih banyak tentang perusahaan dibandingkan dengan principal. Hal tersebut memicu timbulnya ketidakseimbangan informasi (asymmetrical information) antara principal dan agent. Asimetri informasi antara principal dan agent dapat memberikan kesempatan kepada agent untuk menyembunyikan beberapa informasi yang tidak diketahui principal yaitu dengan mempengaruhi angka-angka akuntansi yang disajikan dalam laporan keuangan dengan cara melakukan earnings management.

Kedua, konflik antara pemegang saham dengan kreditur. Kreditur menerima uang dalam jumlah tetap dari perusahaan (bunga hutang), sedangkan pendapatan pemegang saham bergantung pada besaran laba perusahaan. Dalam situasi ini, kreditur lebih memperhatikan kemampuan perusahaan untuk membayar kembali utangnya, dan pemegang saham lebih memperhatikan kemampuan perusahaan untuk memperoleh kembalian yang besar, yaitu dengan melakukan investasi pada proyek-proyek yang berisiko. Apabila pelaksanaan proyek yang berisiko itu berhasil maka kreditur tidak dapat menikmati keberhasilan tersebut, tetapi 
apabila proyek mengalami kegagalan, kreditur mungkin akan menderita kerugian akibat dari ketidakmampuan pemegang saham untuk memenuhi kewajibannya. Untuk mengantisipasi kemungkinan rugi, maka kreditur melakukan pembatasan penggunaan hutang oleh manajer dengan membatasi jumlah penggunaan hutang untuk investasi dalam proyek baru.

\section{Positive Accounting Theory}

Watts dan Zimmerman dalam Ivani (2015) merumuskan tiga hipotesis dalam Positive Accounting Theory yang dapat dijadikan dasar pemahaman tindakan manajemen laba, pertama, the bonus plan hypothesis. Hipotesis ini menyatakan bahwa bonus yang besar dapat memberikan motivasi bagi manajer untuk meningkatkan kinerja suatu perusahaan dalam satu periode. Besarnya bonus yang diberikan kepada pihak internal perusahaan, khususnya para manajer, dihitung berdasarkan laba yang telah diperoleh dan dilaporkan selama tahun berjalan. Hal ini akan mendorong para manajer untuk memilih prosedur akuntansi yang dapat menggeser laba dari periode yang akan datang ke periode saat ini. Kedua, the debt to equity hypothesis. Hipotesis ini menyatakan bahwa melalui adanya perjanjian utang, pihak manajer akan memilih prosedur akuntansi yang dapat meningkatkan laba melalui penggeseran laba dari periode yang akan datang ke periode saat ini. Peningkatan laba ini dilakukan dalam rangka untuk menjaga reputasi perusahaan terutama bagi pihak kreditur. Ketiga, the political cost hypothesis. Hipotesis ini menyatakan bahwa semakin besar perusahaan, maka semakin besar pula keinginan perusahaan untuk meminimalisir laba dengan menggunakan prosedur akuntansi tertentu. Hal ini disebabkan karena faktor-faktor political cost yang dikeluarkan akan tinggi dan sebanding dengan perusahaan yang besar. Sebagai contoh, tingginya laba perusahaan akan berdampak pada tingginya pajak yang akan dibayarkan perusahaan. Oleh karena itu, perusahaan akan berusaha untuk meminimalisir laba yang diperoleh selama tahun berjalan.

\section{Kinerja}

Menurut Subramanyam dan Wild (2014) laba (income disebut juga earnings atau profit) merupakan ringkasan hasil bersih aktivitas operasi usaha dalam periode tertentu yang dinyatakan dalam istilah keuangan. Laba merupakan informasi perusahaan paling diminati dalam pasar uang. Laba memiliki dua peranan, yaitu: pertama, laba ditugaskan untuk menyediakan, baik pengukuran perubahan kekayaan pemegang saham selama periode maupun mengestimasi laba usaha sekarang, yaitu sampai sejauh mana perusahaan dapat menutupi biaya operasi dan menghasilkan pengembalian kepada pemegang sahamnya. Kedua, laba juga digunakan sebagai indikator profitabilitas perusahaan dalam mengestimasi potensi laba di masa depan.

Kinerja perusahaan adalah suatu tampilan keadaan secara utuh atas perusahaan selama periode waktu tertentu, merupakan hasil atau prestasi yang dipengaruhi oleh kegiatan operasional perusahaan dalam memanfaatkan sumber daya-sumber daya yang dimiliki. Kinerja merupakan suatu istilah secara umum yang digunakan untuk sebagian atau seluruh tindakan atau aktivitas dari suatu organisasi pada suatu periode dengan referensi pada jumlah standar seperti biaya-biaya masa lalu atau yang diproyeksikan, dengan dasar efisiensi, akuntabilitas manajemen dan semacamnya (Srimindarti, 2004).

Menurut Standar Akuntansi Keuangan (SAK) kinerja perusahaan dapat diukur dengan menganalisa dan mengevaluasi laporan keuangan. Informasi posisi keuangan dan kinerja keuangan dimasa lalu sering kali digunakan sebagai dasar untuk memprediksi posisi keuangan dan kinerja dimasa depan. Kinerja perusahaan berkaitan dengan bagaimana perusahaan memanfaatkan sumber daya yang mereka miliki dalam mencapai tujuan perusahaan.

Analisis rasio yang dapat digunakan dalam penilaian kinerja keuangan perusahaan 
(Kasmir, 2013), meliputi 1) rasio likuiditas. Selanjutnya, Kasmir menyatakan bahwa rasio likuiditas digunakan untuk menunjukkan atau mengukur kemampuan perusahaan dalam memenuhi kewajibannya yang jatuh tempo, baik kewajiban kepada pihak luar perusahaan maupun di dalam perusahaan. Atau dengan kata lain rasio likuiditas menunjukkan kemampuan perusahaan untuk membayar utang-utang (kewajiban) jangka pendeknya yang jatuh tempo atau rasio yang digunakan untuk mengetahui kemampuan perusahaan dalam membiayai dan memenuhi kewajiban (utang) pada saat ditagih. Jenis-jenis rasio likuiditas yang sering digunakan perusahaan untuk mengukur kemampuan yaitu (1) Current Ratio (Rasio Lancar), Quick Ratio (Rasio Cepat), (2) Cash Ratio (Rasio Kas), (3) Leverage Ratio (Rasio Solvabilitas).

Lebih lanjut, Kasmir (2013) mengemukakan bahwa rasio solvabilitas merupakan rasio yang digunakan untuk mengukur sejauh mana aktiva perusahaan dibiayai dengan utang. Artinya besarnya jumlah utang yang digunakan perusahaan untuk membiayai kegiatan usahanya jika dibandingkan dengan menggunakan modal sendiri. Dengan kata lain, berapa besar beban utang yang ditanggung perusahaan dibandingkan dengan aktivanya. Dalam arti luas dikatakan bahwa rasio solvabilitas digunakan untuk mengukur kemampuan perusahaan untuk membayar seluruh kewajibannya, baik jangka pendek maupun jangka panjang apabila perusahaan dilikuidasi (dibubarkan). Jenis-jenis rasio solvabilitas yang sering digunakan perusahaan untuk mengukur kemampuan yaitu 1) Debt to Asset Ratio; 2) Debt to Equity Ratio; 3) Times Interest Earned; 4) Fixed Charge Coverage; dan 5) Activity Ratio.

\section{Earnings Management}

Scott (2015) mendefinisikan earnings management sebagai pemilihan kebijakan akuntansi oleh manajer, atau tindakan yang dapat mempengaruhi laba, yang bertujuan untuk mencapai beberapa tujuan dalam pelaporan laba. Terdapat dua cara pandang dalam memahami manajemen laba yang dilakukan manajer perusahaan: pertama, bertujuan untuk memaksimalkan utilitas manajemen (opportunistic behavior). Kedua, bertujuan untuk memberikan keuntungan kepada semua pihak yang terkait dalam kontrak (efficient contracting) dimana manajemen laba memberi manajer suatu fleksibilitas untuk melindungi diri mereka dan perusahaan dalam mengantisipasi kejadian-kejadian yang tak terduga untuk keuntungan pihak-pihak yang terlibat dalam kontrak, apabila manajemen laba bersifat oportunis, maka informasi laba tersebut dapat menyebabkan pengambilan keputusan investasi yang salah bagi investor.

\section{Motivasi Earnings Management}

Motivasi manajer perusahaan dalam melakukan manajemen laba menurut Scott (2015) antara lain sebagai berikut. Pertama, bonus purpose (rencana bonus); kedua, debt covenant (kontrak utang jangka panjang); ketiga, political motivation (motivasi politik); keempat, taxation motivation (motivasi perpajakan); kelima, pergantian CEO; keenam, Initial Public Offering (penawaran saham perdana).

Sedangkan, pola earnings management yang dapat dilakukan oleh perusahaan menurut Scott (2015) ada empat, yaitu, pertama taking a big bath. Tindakan ini dilakukan ketika keadaan buruk yang tidak menguntungkan dan tidak bisa dihindari pada periode berjalan, dengan cara mengakui biaya-biaya pada periode-periode yang akan datang dan kerugian periode berjalan. Kedua, income minimization. Income minimization dilakukan saat perusahaan memperoleh profitabilitas yang tinggi dengan tujuan agar tidak mendapat perhatian secara politis. Kebijakan yang diambil bisa berupa pembebanan pengeluaran iklan, riset dan pengembangan yang cepat dan sebagainya. Ketiga, income maximization. Income maximization yaitu memaksimalkan laba agar memperoleh bonus yang lebih besar. 
Demikian pula dengan perusahaan yang mendekati suatu pelanggaran kontrak utang jangka panjang, manajer perusahaan tersebut akan cenderung untuk memaksimalkan laba. Keempat, income smoothing. Income smoothing merupakan bentuk manajemen laba yang dilakukan dengan cara menaikkan dan menurunkan laba untuk mengurangi fluktuasi laba yang dilaporkan sehingga perusahaan terlihat stabil dan tidak berisiko tinggi.

\section{Model Pendeteksian Earnings Management}

Terdapat beberapa metode pendeteksian earnings management yang dapat digunakan dalam penelitian, antara lain sebagai berikut (Andayani, 2010).

\section{The Healy Model}

Healy (1985) menguji manajemen laba dengan membandingkan mean total akrual dengan pembagian variabel manajemen laba. Penyelidikan Healy berbeda dari sebagian besar penyelidikan manajemen laba, dimana Healy memprediksikan bahwa sistematis manajemen laba terjadi di setiap periode. Rumus the Healy Model untuk nondiscretionary accrual adalah:

$$
\mathrm{NDA}_{\mathrm{t}}=\frac{\sum \mathrm{TA}}{\mathrm{T}}
$$

Dimana:

NDA = estimasi nondiscretionary accrual

TA $\quad=$ total akrual

$\mathrm{T}=$ tahun yang termasuk dalam periode estimasi

$\mathrm{t} \quad=$ tahun

The Healy Model lebih efektif dalam mendeteksi manajemen laba pada sebagian besar keadaan. Metode ini dapat menyediakan cara yang mudah bagi investor untuk mengevaluasi kemungkinan suatu perusahaan melakukan manajemen laba tanpa menggunakan metode statistik.

\section{The Jones Model}

Jones model (1991) mengemukakan sebuah model yang mengasumsikan bahua non discretionary accruals tetap konstan. Jones model juga mengasumsikan bahwa perubahan pendapatan dan aktiva tetap bruto merupakan akrual yang ditimbulkan dari transaksi ekonomi perusahaan dan bersifat tidak dapat dikelola (unmanaged).

Pokok permasalahan utama dalam penggunaan metode ini adalah keharusan untuk mengidentifikasi dan memisahkan total akrual ke dalam komponen-komponen yang tidak dikelola (unmanaged component) dan yang dikelola (munaged component).

Rumus the Jones model untuk nondiscretionary accruals adalah:

$$
\mathrm{NDA}_{t}=a_{1}\left(\frac{1}{\mathrm{~A}_{t-1}}\right)+a_{2}\left(\Delta \mathrm{REV}_{t}\right)+a_{3}\left(\mathrm{PPE}_{t}\right)
$$

Dimana:

$\triangle \mathrm{REV}_{\mathrm{t}} \quad=$ pendapatan pada tahun $\mathrm{t}$ dikurangi pendapatan pada tahun $\mathrm{t}-1$

$\mathrm{PPE}_{\mathrm{t}} \quad=$ property, plant, and equipment pada tahun $\mathrm{t}$

$\mathrm{A}_{\mathrm{t}-1} \quad=$ total aset pada $\mathrm{t}-1$

$\alpha_{1}, \alpha_{2}, \alpha_{3} \quad=$ parameter spesifik perusahaaan 


\section{The Modified Jones Model}

Dechow, et al., (1995) memodifikasi Jones model yang dirancang untuk mengeliminasi dugaan kecenderungan Jones model untuk mengukur discretionary accruals dengan kesalahan saat discretion diaplikasikan pada pendapatan. Modified Jones model mengasumsikan bahwa semua perubahan penjualan kredit pada event period merupakan hasil dari manajemen laba. Hal ini didasarkan pada alasan bahwa lebih mudah untuk mengatur laba dengan mengaplikasikan discretion pada pengakuan pendapatan pada penjualan kredit di event period daripada mengaplikasikan discretion pada penjualan tunai. The Modified Jones model diformulasikan sebagai berikut:

$$
\mathrm{NDA}_{t}=a_{1}\left(\frac{1}{\mathrm{~A}_{t-1}}\right)+a_{2}\left(\Delta \mathrm{REV}_{t}-\Delta \mathrm{REC}_{t}\right)+a_{3}\left(\mathrm{PPE}_{t}\right)
$$

Keterangan:

$\triangle \mathrm{REV}_{\mathrm{t}} \quad=$ pendapatan pada tahun $\mathrm{t}$ dikurangi pendapatan pada tahun $\mathrm{t}-1$

$\triangle \mathrm{REC}_{\mathrm{t}} \quad=$ selisih piutang bersih pada tahun $\mathrm{t}$ dan piutang bersih pada tahun $\mathrm{t}-1$.

$\mathrm{PPE}_{\mathrm{t}} \quad=$ property, plant, and equipment pada tahun $\mathrm{t}$

$\mathrm{A}_{\mathrm{t}-1} \quad=$ total aset pada $\mathrm{t}-1$

$\alpha_{1}, \alpha_{2}, \alpha_{3} \quad=$ parameter spesifik perusahaaan

\section{The Cross-Sectional Models}

Baik model Jones cross-sectional dan Jones model modifikasi cross-sectional adalah sama dengan Jones model dan modified Jones model, kecuali bahwa parameter diestimasi dengan menggunakan data cross-sectional bukan data time series. Model cross-sectional mengasumsikan bahwa korelasi antara akrual non kelolaan dan penentuan akrual, seperti perubahan dalam pendapatan dan PPE (bruto), ditentukan oleh kelompok industri dan situasi ekonomi sekarang sedangkan model time series mengasumsikan bahwa korelasi ditentukan oleh karakteristik spesifik perusahaan.

\section{Akrual Khusus}

$\mathrm{NDA}_{i t}=\alpha_{0}+\alpha_{1} \mathrm{CO}_{i t}+\alpha_{2} \mathrm{LOAN}_{i t}+\alpha_{3} \mathrm{NPA}_{i t}+\alpha_{4} \Delta \mathrm{NPA}_{i t}+\mathrm{e}$

Keterangan:

COit = loan charge-off (pinjaman yang dihapusbukukan)

LOAN = loans outstanding (pinjaman yang beredar)

NPA = nonperforming assets (asset produktif yang bermasalah)

$\triangle \mathrm{NPA}=$ selisih nonperforming assets.

\section{Cost of Debt}

Cost of debt dapat didefinisikan sebagai tingkat yang harus diterima dari investasi untuk mencapai tingkat pengembalian (yield rate) yang dibutuhkan oleh kreditur atau dengan kata lain adalah tingkat pengembalian yang dibutuhkan oleh kreditur saat melakukan pendanaan dalam suatu perusahaan (Fabozzi, 2007). Sedangkan menurut Arjo dalam Ratnasari (2014) cost of debt merupakan tingkat pengembalian yang harus dilunasi oleh perusahaan terhadap hutang-hutangnya.

Hutang yang dimaksud dapat diperoleh dari lembaga pembiayaan atau dengan menerbitkan surat pengakuan hutang (obligasi). Cost of debt yang berasal dari pinjaman adalah merupakan bunga yang harus dibayar perusahaan, sedangkan cost of debt dengan 
menerbitkan obligasi adalah tingkat pengembalian hasil yang diinginkan (required of return) yang diharapkan investor yang digunakan sebagai tingkat diskonto dalam mencari nilai obligasi. Perusahaan memanfaatkan sumber pembelanjaan hutang, dengan tujuan untuk memperbesar tingkat pengembalian modal sendiri (ekuitas).

Terdapat beberapa metode yang dapat digunakan untuk mengukur cost of debt, antara lain sebagai berikut.

Pertama, cost of debt dihitung dari besarnya beban bunga yang dibayarkan oleh perusahaan tersebut dalam periode satu tahun dibagi dengan jumlah pinjaman yang menghasilkan bunga tersebut (Francis, et al., 2005). Sehingga cost of debt dapat dirumuskan sebagai berikut.

$$
\mathrm{COD}=\frac{\text { Interest Expense }}{\text { Average Long Term Debt }}
$$

Keterangan:

COD

Interest Expense

Average Long Term Debt
= biaya utang pada periode $\mathrm{t}+1$

= biaya bunga pada periode $\mathrm{t}$

$=$ rata-rata pinjaman yang menghasilkan bunga

Kedua, perhitungan yang dilakukan oleh Sutrisno (2009), yang mana biaya utang dibagi menjadi dua macam yaitu:

1) Biaya utang sebelum pajak (before tax cost of debt)

Besarnya biaya hutang sebelum pajak dapat ditentukan dengan menghitung besarnya tingkat hasil internal (yield to maturity) atas arus kas obligasi yang dinotasikan dengan $\mathrm{Kd}$.

$$
\mathrm{K}_{\mathrm{d}}=\frac{\text { Beban Hutang }}{\text { Hutang Jangka Panjang }}
$$

2) Biaya utang setelah pajak (after tax cost of debt)

Perusahaan yang menggunakan sebagian sumber dananya dari hutang akan terkena kewajiban membayar bunga. Bunga merupakan salah satu bentuk beban bagi perusahaan (interest expense). Dengan adanya beban bunga ini akan menyebabkan besarnya pembayaran pajak penghasilan menjadi berkurang. Oleh karena itu, biaya modal yang dihitung juga harus setelah pajak maka biaya hutang ini perlu disesuaikan dengan pajak.

$$
\mathrm{K}_{\mathrm{i}}=\mathrm{K}_{\mathrm{d}}(1-\mathrm{T})
$$

$$
\begin{aligned}
& \text { Keterangan: } \\
& \mathrm{K}_{\mathrm{i}}=\text { Biaya utang setelah pajak } \\
& \mathrm{K}_{\mathrm{d}}=\text { Biaya hutang sebelum pajak } \\
& \mathrm{T} \quad=\text { Tarif pajak }
\end{aligned}
$$

Ketiga, menurut Anderson et al., (2003) cost of debt diproksi menggunakan yield spread (Spread), atau selisih antara weighted-average yield to maturity on the firm's outstanding traded debt and yield to maturity on a Treasury security with corresponding duration.

\section{Kerangka Berpikir}

Kerangka pemikiran penelitian ini menunjukkan pengaruh variabel independen terhadap variabel dependen dengan adanya variabel pemoderasi. Variabel independen dalam penelitian 
ini adalah kinerja perusahaan dan variabel dependennya adalah cost of debt dengan earnings management sebagai variabel pemoderasi. Kerangka pemikiran dalam penelitian ini dapat digambarkan sebagai berikut:

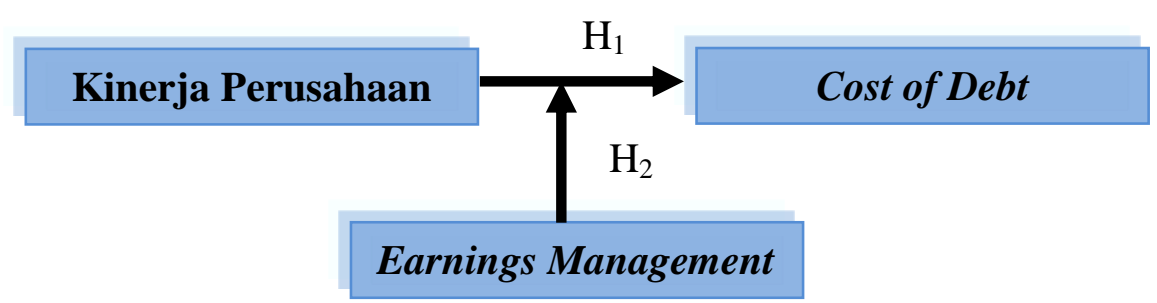

Gambar 1. Kerangka Konseptual Penelitian

\section{Pengembangan Hipotesis \\ Kinerja Perusahaan dan Cost of Debt}

Analisis kinerja perusahaan dibutuhkan kreditor untuk menilai kemampuan perusahaan dalam memenuhi kewajiban finansialnya. Kinerja perusahaan berkaitan dengan bagaimana perusahaan memanfaatkan sumber daya yang mereka miliki dalam mencapai tujuan perusahaan. Kinerja perusahaan berkaitan juga dengan prospek perusahaan di masa datang. Kinerja perusahaan yang baik tentunya akan memiliki risiko yang rendah (Amalina, 2017). Dengan rendahnya risiko yang diterima kreditor biaya hutang (cost of debt) akan rendah pula. Dengan demikian, jika kinerja perusahaan baik maka tidak diimbangi dengan naiknya biaya hutang (cost of debt) dalam pendanaan perusahaan. Berdasarkan hal tersebut maka dapat dirumuskan hipotesis:

\section{$\mathrm{H}_{1}$ : Kinerja perusahaan berpengaruh negatif terhadap cost of debt}

\section{Earnings Management, Kinerja dan Cost of Debt.}

Prevost, et al., (2008) melaporkan bahwa earnings management berpengaruh positif terhadap cost of debt. Pihak manajer cenderung melakukan earnings management, untuk meningkatkan laba yang dilaporkan, karena dengan laba yang tinggi pihak kreditor akan merespon baik tentang kinerja perusahaan. Perusahaan dengan kinerja yang baik sangat sedikit kemungkinan melakukan manajemen laba (Pratiwi, 2015). Sebaliknya, apabila kreditor mengetahui praktik earnings management dilakukan oleh perusahaan, kreditor akan memandang buruk kinerja perusahaan, sehingga kreditor menilai risiko atas informasi yang ditanggungnya lebih tinggi, semakin tinggi risiko yang ditanggung kreditor, maka semakin tinggi pula cost of debt yang dikeluarkan oleh perusahaan, karena dengan adanya earnings manajement maka kreditor bereaksi dengan memperketat perjanjian kredit yang kemudian akan meningkatkan biaya hutang (cost of debt). Berdasarkan hal tersebut maka dapat dirumuskan hipotesis:

$\mathrm{H}_{2}$ : Earnings management memoderasi (memperlemah) hubungan kinerja perusahaan dengan cost of debt.

\section{METODE PENELITIAN}




\section{Strategi Penelitian}

Strategi penelitian yang digunakan dalam penelitian ini adalah metode penelitian kuantitatif. Menurut Sugiyono (2013), metode penelitian kuantitatif dapat diartikan sebagai metode penelitian yang berlandaskan pada filsafat positivisme, digunakan untuk meneliti pada populasi atau sampel tertentu, teknik pengambilan sampel pada umumnya dilakukan secara random, pengumpulan data menggunakan instrumen penelitian, analisis data bersifat kuantitatif/statistik dengan tujuan untuk menguji hipotesis yang telah ditetapkan.

\section{Model Pengujian Hipotesis}

Penelitian ini menggunakan metode estimasi model regresi dengan menggunakan data panel. Penggunaan data panel dalam regresi akan menghasilkan intersep dan slope yang berbeda pada setiap entitas/perusahaan dan setiap periode waktu. Model regresi data panel yang akan diestimasi membutuhkan asumsi terhadap intersep, slope dan variabel gangguannya. Untuk menguji apakah ada hubungan antara variabel independen dengan variabel dependen dengan adanya variabel moderating dengan estimasi regresi data panel, persamaan model regresinya dalam penelitian ini adalah:

\begin{tabular}{|c|c|}
\hline \multirow{2}{*}{\multicolumn{2}{|c|}{$\begin{array}{l}\text { I. } \quad Y_{i t}=\alpha+\beta_{1} X_{1 i t}+\varepsilon \\
\text { Keterangan: }\end{array}$}} \\
\hline & \\
\hline$Y_{\text {it }}$ & $=$ Cost of debt \\
\hline $\mathrm{X}_{1 \mathrm{it}}$ & $=$ Kinerja perusahaan \\
\hline $\mathrm{X}_{2 \mathrm{it}}$ & $=$ Earnings management \\
\hline $\mathrm{X}_{1 \mathrm{it}} \mathrm{X}_{2 \mathrm{it}}$ & $=$ Interaksi antara kinerja perusahaan dan earnings management \\
\hline$\alpha$ & $=$ Konstanta \\
\hline$\beta_{1-3}$ & $=$ Koefisien regresi \\
\hline$\varepsilon$ & $=$ Error term \\
\hline $\mathrm{i}$ & $=$ Entitas ke-i \\
\hline $\mathrm{t}$ & $=$ Periode ke- $\mathrm{t}$ \\
\hline
\end{tabular}

\section{Definisi dan Operasionalisasi Variabel Variabel Independen}

Variabel independen dalam penelitian ini adalah kinerja perusahaan. Kinerja perusahaan adalah suatu tampilan keadaan secara utuh atas perusahaan selama periode waktu tertentu, merupakan hasil atau prestasi yang dipengaruhi oleh kegiatan operasional perusahaan dalam memanfaatkan sumber daya-sumber daya yang dimiliki. Kinerja perusahaan diukur dengan menggunakan rasio profitabilitas yaitu Return on Equity (ROE).

$$
\mathrm{ROE}=\frac{\text { Earning After Interest and Tax }(\mathrm{EAT})}{\text { Ekuitas }}
$$

\section{Variabel Dependen}

Variabel dependen dalam penelitian ini adalah cost of debt. Cost of debt dapat didefinisikan sebagai tingkat yang harus diterima dari investasi untuk mencapai tingkat pengembalian (yield rate) yang dibutuhkan oleh kreditur atau dengan kata lain adalah tingkat pengembalian yang dibutuhkan oleh kreditur saat melakukan pendanaan dalam suatu perusahaan (Fabozzi, 2007). Cost of debt dihitung dari besarnya beban bunga yang dibayarkan oleh perusahaan tersebut dalam periode satu tahun dibagi dengan jumlah pinjaman yang menghasilkan bunga tersebut. Sengupta (1998), Francis et al., (2005) dan Nugroho (2014) juga menggunakan interest rate dari hutang perusahaan untuk menghitung 
besarnya cost of debt yang diterima perusahaan. Cost of debt dengan rumus sebagai berikut.

$$
\mathrm{COD}=\frac{\text { Interest Expense }}{\text { Average Long Term Debt }}
$$

Keterangan:

COD $($ Cost of Debt $) \quad$ = biaya hutang pada periode $\mathrm{t}+1$

Interest Expense = biaya bunga pada periode $\mathrm{t}$

Average Long Term Debt = rata-rata pinjaman yang menghasilkan bunga

\section{Variabel Moderasi}

Variabel pemoderasi dalam penelitian ini adalah earnings management. Earnings management merupakan pemilihan kebijakan akuntansi oleh manajer, atau tindakan yang dapat mempengaruhi laba, yang bertujuan untuk mencapai beberapa tujuan dalam pelaporan laba (Scott, 2015). Pengukuran earnings management dilakukan dengan cara menghitung discreationary accrual. Pengukuran discreationary accrual sebagai proksi earnings management menggunakan Jones model (1991) yang dimodifikasi oleh Dechow, dkk. (1995) atau yang biasa dikenal dengan Modified Jones model. Model ini digunakan karena dinilai merupakan model yang paling baik dalam mendeteksi earnings management. Berikut langkah-langkah mendapatkan nilai discreationary accrual.

1) Menghitung total akrual

$\mathrm{TA}_{\mathrm{t}}=\mathrm{NI}_{\mathrm{t}}-\mathrm{CFO}_{\mathrm{t}}$

2) Menghitung nilai akrual dengan persamaan regresi linear sederhana

$$
\frac{\mathrm{TA}_{\mathrm{t}}}{\mathrm{A}_{t-1}}=a_{1}\left(\frac{1}{\mathrm{~A}_{t-1}}\right)+a_{2}\left(\frac{\Delta \mathrm{REV}}{\mathrm{A}_{\mathrm{t}-1}}\right)+a_{3}\left(\frac{\mathrm{PPE}_{\mathrm{t}}}{\mathrm{A}_{\mathrm{t}-1}}\right)+\varepsilon
$$

3) Menghitung nilai nondiscreationary accrual (NDA)

$$
\mathrm{NDA}_{\mathrm{t}}=a_{1}\left(\frac{1}{\mathrm{~A}_{t-1}}\right)+a_{2}\left(\frac{\Delta \mathrm{REV}-\Delta \mathrm{REC}}{\mathrm{A}_{\mathrm{t}-1}}\right)+a_{3}\left(\frac{\mathrm{PPE}_{\mathrm{t}}}{\mathrm{A}_{\mathrm{t}-1}}\right)
$$

4) Menghitung nilai discreationary accrual:

$$
\mathrm{DA}_{\mathrm{t}}=\left(\frac{\mathrm{TA}}{\mathrm{A}_{\mathrm{t}-1}}\right)-\mathrm{NDA}_{\mathrm{t}}
$$

Keterangan:

$\mathrm{TA}_{\mathrm{t}} \quad=$ Total Accruals pada tahun $\mathrm{t}$

$\mathrm{NI}_{\mathrm{t}} \quad=$ Net Income (laba bersih) pada tahun $\mathrm{t}$

$\mathrm{CFO}_{\mathrm{t}}=$ Cash Flow from Operation (kas dari operasi) pada tahun $\mathrm{t}$

$\mathrm{A}_{\mathrm{t}-1} \quad=$ Total Aktiva pada tahun $\mathrm{t}-1$

NDA $_{\mathrm{t}} \quad=$ Non Discretionary Accrual pada tahun $\mathrm{t}$

$\mathrm{DA}_{\mathrm{t}} \quad=$ Discretionary Accrual pada tahun $\mathrm{t}$

$\triangle \mathrm{REC}=$ Perubahan piutang (piutang bersih pada tahun $\mathrm{t}$ dikurangi piutang bersih pada tahun t-1 dibagi total aktiva pada tahun t-1)

$\triangle \mathrm{REV}=$ Perubahan pendapatan (Pendapatan pada tahun $\mathrm{t}$ dikurangi pendapatan tahun $\mathrm{t}-$ 1)

$\mathrm{PPE}_{\mathrm{t}} \quad=$ Aktiva tetap pada tahun $\mathrm{t}$

Tabel 2. Definisi Operasional Variabel 


\begin{tabular}{|c|c|c|c|}
\hline Variabel & Pengertian & Indikator & Jenis Data \\
\hline $\begin{array}{l}\text { Independen: } \\
\text { Kinerja } \\
\text { Perusan }\end{array}$ & $\begin{array}{l}\text { Hasil atau prestasi yang } \\
\text { dipengaruhi oleh kegiatan } \\
\text { operasional perusahaan } \\
\text { dalam memanfaatkan } \\
\text { sumber daya. }\end{array}$ & $\begin{array}{l}\mathrm{ROE}= \\
\frac{\text { Earning After Interest and }}{\text { Ekuitas }}\end{array}$ & Rasio \\
\hline $\begin{array}{l}\text { Dependen: } \\
\text { Cost of Debt }\end{array}$ & $\begin{array}{l}\text { Tingkat pengembalian yang } \\
\text { dibutuhkan oleh kreditur saat } \\
\text { melakukan pendanaan dalam } \\
\text { suatu perusahaan. }\end{array}$ & $\begin{array}{l}\mathrm{COD}= \\
\frac{\text { Interest Expense }}{\text { Average Long Term Debt }}\end{array}$ & Rasio \\
\hline $\begin{array}{l}\text { Pemoderasi: } \\
\text { Earnings } \\
\text { Management }\end{array}$ & $\begin{array}{l}\text { Pemilihan kebijakan } \\
\text { akuntansi oleh manajer, yang } \\
\text { bertujuan untuk mencapai } \\
\text { beberapa tujuan dalam } \\
\text { pelaporan laba. }\end{array}$ & $\mathrm{DA}_{\mathrm{t}}=\left(\frac{\mathrm{TA}_{\mathrm{t}}}{\mathrm{A}_{\mathrm{t}-1}}\right)-\mathrm{NDA}_{\mathrm{t}}$ & Rasio \\
\hline
\end{tabular}

\section{Data Penelitian}

Jenis data dalam penelitian yaitu data sekunder yang diperoleh melalui penelusuran dokumen yang berupa bukti, catatan atau laporan historis yang telah tersusun dalam arsip baik dokumentasi yang dipublikasikan maupun yang tidak dipublikasikan (Indriantoro \& Supomo dalam Fitriyani, 2014). Data yang digunakan berupa data laporan keuangan perusahaan manufaktur yang listing di Bursa Efek Indonesia (BEI) selama periode 20132015. Data diperoleh dari Indonesian Capital Market Directory (ICMD) dan website Bursa Efek Indonesia.

\section{Analisis Data}

Teknik pengolahan data dalam penelitian ini menggunakan penghitungan komputasi program Eviews 9,5 karena program ini memiliki kemampuan analisis statistik cukup tinggi serta sistem manajemen data pada lingkungan grafis menggunakan menu-menu deskriptif dan kotak-kotak dialog sederhana, sehingga mudah dipahami cara pengoperasiannya.

\section{Model Regresi Data Panel}

Menurut Widarjono (2007) untuk mengestimasi parameter model dengan data panel, terdapat tiga teknik (model) dalam estimasi data panel yaitu sebagai berikut.

\section{Common Effect Model}

Teknik ini merupakan teknik yang paling sederhana untuk mengestimasi parameter model data panel, yaitu dengan mengkombinasikan data cross section dan time series sebagai satu kesatuan tanpa melihat adanya perbedaan waktu dan entitas (individu). Dimana pendekatan yang sering dipakai adalah metode Ordinary Least Square (OLS). Model Commen Effect mengabaikan adanya perbedaan dimensi individu maupun waktu atau dengan kata lain perilaku data antar individu sama dalam berbagai kurun waktu.

\section{Fixed Effect Model}

Pendekatan ini mengasumsikan bahwa intersep dari setiap individu adalah berbeda sedangkan slope antar individu adalah tetap (sama). Teknik ini menggunakan variabel dummy untuk menangkap adanya perbedaan intersep antar individu.

\section{Random Effect Model}

Pendekatan yang dipakai dalam Random Effect mengasumsikan setiap perusahaan 
mempunyai perbedaan intersep, yang mana intersep tersebut adalah variabel random atau stokastik. Model ini sangat berguna jika individu (entitas) yang diambil sebagai sampel adalah dipilih secara random dan merupakan wakil populasi. Teknik ini juga memperhitungkan bahwa error mungkin berkorelasi sepanjang cross section dan time series.

\section{HASIL DAN PEMBAHASAN}

Berdasarkan hasil pengolahan data yang telah dilakukan dengan menggunakan alat analisis, penulis dapat melaporkan hasil penelitian sebagai berikut.

\section{Statistik Deskriptif}

Statistik deskriptif ini digunakan untuk melihat gambaran umum dari data yang digunakan. Adapun statistik deskriptif penelitian ini nampak sebagai berikut.

Tabel 3. Statistik Deskriptif

\begin{tabular}{lllll}
\hline & COD & ROE & DA & ROE*DA \\
\hline Mean & 0,170028 & 0,104006 & 0,004408 & 0,000808 \\
Maximum & 0,514107 & 0,614715 & 0,039188 & 0,021106 \\
Minimum & 0,047947 & $-0,094873$ & $-0,016739$ & $-0,001221$ \\
Std. Dev. & 0,076750 & 0,129770 & 0,008603 & 0,002379 \\
Observation & 90 & 90 & 90 & 90 \\
\hline
\end{tabular}

Sumber: Output Eviews 9,5 hasil proses data

Berdasarkan hasil statistik deskriptif pada Tabel 3 adalah cost of debt (COD) memiliki nilai maksimum sebesar 0,514107 dan nilai minimum sebesar 0,047947 . Nilai rata-rata (mean) sebesar 0,170028 dan standar deviasi untuk variabel cost of debt sebesar 0,076750. Variabel kinerja perusahaan yang diproksikan dengan Return on Equity (ROE) memiliki nilai maksimum sebesar 0,614715 dan nilai minimum sebesar -0,094873. Nilai rata-rata (mean) kinerja perusahaan sebesar 0,104006 dengan standar deviasi sebesar 0,129770. Variabel earnings management yang diproksikan dengan Discretionary Accrual (DA) memiliki nilai maksimum sebesar 0,039188 dan nilai minimum sebesar -0,016739. Nilai rata-rata (mean) earnings management sebesar 0,004408 dengan standar deviasi sebesar 0,008603. Sedangkan, interaksi kinerja perusahaan dan earnings management memiliki nilai maksimum sebesar 0,021106 dan nilai minimum sebesar -0,001221. Dengan nilai rata-rata (mean) sebesar 0,000808 dan standar deviasi sebesar 0,002379.

\section{Analisis Model Regresi Data Panel}

Penelitian ini menggunakan metode estimasi model regresi dengan menggunakan data panel. Dapat dilakukan melalui tiga pendekatan, antara lain: (1) Common Effect Model (CEM), (2) Fixed Effect Model (FEM), dan (3) Random Effect Model (REM).

\section{Common Effect Model (CEM)}

Pada common effect model diasumsikan bahwa tidak ada perbedaan nilai intersep dan slope pada hasil regresi baik atas dasar perbedaan antar individu maupun antar waktu. Metode pendugaan parameter pada model common effect menggunakan metode Ordinary Least Square (OLS). Hasil regresi data panel dengan Common Effect Model dapat dilihat dalam tabel berikut. 
Tabel 4. Hasil Regresi Data Panel Common Effect Model

\begin{tabular}{llrrr}
\hline Variabel & Coefficient & Std. Error & t-Statistic & \multicolumn{1}{c}{ Prob. } \\
\hline C & 0,189373 & 0,010537 & 17,97253 & 0,0000 \\
ROE & $-0,162533$ & 0,069285 & $-2,345871$ & 0,0213 \\
DA & $-0,744229$ & 1,208753 & $-0,615700$ & 0,5397 \\
ROE*DA & 1,040503 & 4,711222 & 0,220856 & 0,8257 \\
\hline
\end{tabular}

Sumber: Output Eviews 9,5 hasil data diproses

Berdasarkan tabel di atas terdapat satu variabel dengan test individual ( $t$-test probability) terlihat signifikan dengan $\alpha=5 \%$ dan nilai adjusted $\mathrm{R}^{2}$ sebesar 0,054253 . Nilai probability dari $f$-stat senilai 0,050548 memberikan arti bahwa model tersebut significant. Dan nilai Durbin-Watson stat sebesar 1,304226 yang belum mendekati range angka 2.

\section{Fixed Effect Model (FEM)}

Metode pendugaan regresi data panel pada Fixed Effect Model menggunakan teknik penambahan variabel dummy atau Least Square Dummy Variabel (LSDV). Hasil regresi data panel dengan Fixed Effect Model disajikan pada berikut ini.

Tabel 5. Hasil Regresi Data Panel Fixed Effect Model

\begin{tabular}{lllll}
\hline Variabel & Coefficient & Std. Error & t-Statistic & Prob. \\
\hline C & 0,186016 & 0,016816 & 11,06187 & 0,0000 \\
ROE & $-0,188555$ & 0,179812 & $-1,048626$ & 0,2988 \\
DA & $-0,409513$ & 1,178801 & $-0,347398$ & 0,7296 \\
ROE*DA & 6,717108 & 5,875510 & 1,143238 & 0,2577 \\
\hline
\end{tabular}

Sumber: Output Eviews 9,5hasil proses data

Pada tabel di atas dapat dilihat bahwa uji $t$-stat tidak terdapat variabel yang memperlihatkan signifikansi $(\alpha=5 \%)$. Selanjutnya, nilai adjusted $\mathrm{R}^{2}$ yaitu 0,341027 . Nilai probability dari $f$-stat senilai 0,001629 memberikan arti bahwa model tersebut signifikan. Serta nilai Durbin-Watson stat sebesar 2,690619 memberikan angka yang sudah melewati range angka 2.

\section{Random Effect Model (REM)}

Random Effect Model diakomodasi lewat error. Metode pendugaan regresi data panel pada Random Effect Model menggunakan metode Generalized Least Square (GLS). Berikut output dari regresi data panel dengan Random Effect Model. 
Tabel 6. Hasil Regresi Data Panel Random Effect Model

\begin{tabular}{lllll}
\hline Variabel & \multicolumn{1}{c}{ Coefficient } & Std. Error & t-Statistic & Prob. \\
\hline C & 0,187436 & 0,012555 & 14,92862 & 0,0000 \\
ROE & $-0,166958$ & 0,081771 & $-2,041771$ & 0,0442 \\
DA & $-0,647398$ & 1,089884 & $-0,594006$ & 0,5541 \\
ROE*DA & 3,478846 & 4,394530 & 0,791631 & 0,4308 \\
\hline
\end{tabular}

Sumber: Output Eviews 9,5 hasil proses data

Pada tabel di atas dapat dilihat bahwa uji $t$-stat terdapat satu variabel yang memperlihatkan signifikansi $(\alpha=5 \%)$. Nilai adjusted $\mathrm{R}^{2}$ memperlihatkan angka yang rendah yaitu 0,022054 . Nilai probability dari $f$-stat senilai 0,179665 memberikan arti bahwa model tersebut tidak signifikan. Serta nilai Durbin-Watson stat sebesar 1,790959 yang mendekati kisaran range angka 2.

Berdasarkan pendekatan model regresi data panel dengan Eviews (Common Effect Model, Fixed Effect Model, dan Random Effect Model) dan uji yang telah dilakukan (Chow Test, Hausman Test, dan Lagrange Multiplier Test) menunjukan bahwa model regresi yang lebih tepat untuk digunakan dalam penelitian ini adalah Random Effect Model. Seperti telah dikatakan Gujarati (2003) pada bukunya menyarankan apabila jumlah data cross section $(\mathrm{N})$ lebih besar dari jumlah data time series (T) maka digunakan metode random effect dalam pengolahannya dan berikut hasilnya.

Tabel 7. Regresi Data Panel dan Uji t Model 1

\begin{tabular}{lllll}
\hline Variabel & Coefficient & Std. Error & t-Statistic & Prob. \\
\hline C & 0,184839 & 0,012221 & 15,12487 & 0,0000 \\
ROE & $-0,142396$ & 0,068361 & $-2,083022$ & 0,0402 \\
\hline
\end{tabular}

Sumber: Output Eviews 9,5 hasil proses data

Berdasarkan hasil regresi pada tabel diatas menunjukkan model regresi untuk pengaruh variabel kinerja perusahaan yang diproksikan dengan Return on Equity (ROE) terhadap variabel cost of debt (COD) adalah sebagai berikut. Konstanta $\alpha$ sebesar 0,184839 menyatakan bahwa jika variabel X konstan, maka variabel Y adalah 0,184839. Selanjutnya, koefisien regresi X (ROE) sebesar -0,142396 menyatakan bahwa setiap penambahan variabel $\mathrm{X}$ (kinerja perusahaan) sebesar $1 \%$ akan menurunkan variabel Y (cost of debt) sebesar 0,142396 dengan asumsi variabel bebas lain besarnya konstan.

Sedangkan, untuk hasil preses selanjutnya yaitu uji dengan menggunakan model 2 , hasilnya dapat dilihat sebagai berikut. 
Tabel 8. Regresi Data Panel dan Uji t Model 2

\begin{tabular}{lllll}
\hline Variabel & \multicolumn{1}{c}{ Coefficient } & Std. Error & t-Statistic & Prob. \\
\hline C & 0,187436 & 0,012555 & 14,92862 & 0,0000 \\
ROE & $-0,166958$ & 0,081771 & $-2,041771$ & 0,0442 \\
DA & $-0,647398$ & 1,089884 & $-0,594006$ & 0,5541 \\
ROE*DA & 3,478846 & 4,394530 & 0,791631 & 0,4308 \\
\hline
\end{tabular}

Sumber: Output Eviews 9,5 hasil proses data

Berdasarkan hasil regresi di atas, maka dapat diperoleh suatu persamaan garis regresi sebagai berikut. Konstanta $\alpha$ sebesar 0,187436 menyatakan bahwa jika variabel $\mathrm{X}$ konstan, maka variabel Y adalah 0,187436. kemudian, koefisien regresi $\mathrm{X}_{1}(\mathrm{ROE})$ sebesar -0,166958 menyatakan bahwa setiap penambahan variabel $X_{1}$ (kinerja perusahaan) sebesar $1 \%$ akan menurunkan variabel Y (cost of debt) sebesar 0,166958 dengan asumsi variabel bebas lain besarnya konstan. Selanjutnya, koefisien regresi $X_{2}$ (DA) sebesar $-0,647398$ menyatakan bahwa setiap penambahan variabel $\mathrm{X}_{2}$ (earnings management) sebesar $1 \%$ akan menurunkan variabel $\mathrm{Y}$ (cost of debt) sebesar 0,647398 dengan asumsi variabel bebas lain besarnya konstan. Koefisien regresi $\mathrm{X}_{3}$ (ROE*DA) sebesar 3,478846 menyatakan bahwa setiap penambahan variabel $\mathrm{X}_{3}$ (earnings management sebagai variabel moderasi) sebesar $1 \%$ akan meningkatkan variabel Y (cost of debt) sebesar 3,478846 dengan asumsi variabel bebas lain besarnya konstan.

\section{PEMBAHASAN}

\section{Kinerja Perusahaan dan Cost of Debt}

Berdasarkan hasil penelitian dapat disimpulkan bahwa kinerja perusahaan berpengaruh negatif terhadap cost of debt. Hasil ini mendukung penelitian Amalina (2017) yang menyatakan bahwa kinerja perusahaan yang baik tentunya akan memiliki risiko yang rendah. Artinya dengan rendahnya risiko yang diterima kreditor biaya hutang (cost of debt) akan rendah pula. Hal ini dikarenakan kinerja perusahaan yang baik akan mempengaruhi persepsi para kreditor atas kemampuan perusahaan dalam memenuhi kewajiban finansialnya dan mampu memberikan return yang optimal, sehingga memiliki resiko yang rendah. Maka dengan rendahnya risiko yang diterima kreditor biaya hutang (cost of debt) akan rendah pula. Dengan demikian, jika kinerja perusahaan baik maka tidak diimbangi dengan naiknya biaya hutang (cost of debt) dalam pendanaan perusahaan.

\section{Earnings Management, Kinerja dan Cost of Debt}

Hasil penelitian ini menyimpulkan bahwa earnings management memoderasi (memperlemah) hubungan kinerja perusahaan dengan cost of debt. Hal ini sesuai dengan agency theory, dimana dengan adanya asimetri informasi, agent memiliki lebih banyak informasi penting mengenai kondisi dan kinerja keuangan perusahaan dibandingkan dengan principal. Hal ini dimanfaatkan agent untuk melakukan earnings management untuk membuat kinerja perusahaan terlihat baik dalam laporan keuangan. Namun, ketika kreditor mengetahui praktik earnings management yang dilakukan oleh perusahaan, kreditor tidak lagi mengapresiasi kinerja keuangan perusahaan tersebut. Hal itu dikarenakan kinerja keuangan perusahaan tersebut bukan dipengaruhi oleh kinerja perusahaan yang sesungguhnya, tetapi juga dipengaruhi oleh kebijakan akuntansi yang digunakan oleh manajemen. 


\section{KESIMPULAN}

Berdasarkan hasil penelitian dan pembahasan yang telah disajikan pada bab-bab sebelumnya, maka dapat diambil kesimpulan sebagai berikut. Pertama, variabel kinerja perusahaan berpengaruh negatif terhadap cost of debt pada perusahaan manufaktur yang terdaftar di Bursa Efek Indonesia (BEI). Artinya kinerja perusahaan yang baik maka tidak diimbangi dengan naiknya biaya hutang (cost of debt) dalam pendanaan perusahaan. Hal ini dikarenakan kinerja perusahaan yang baik akan memiliki risiko yang rendah, maka dengan rendahnya risiko yang diterima kreditor biaya hutang (cost of debt) akan rendah pula. Kedua, variabel earnings management memoderasi (memperlemah) hubungan kinerja perusahaan dengan cost of debt pada perusahaan manufaktur yang terdaftar di Bursa Efek Indonesia (BEI). Hal ini sesuai dengan agency theory, dimana dengan adanya asimetri informasi, dimanfaatkan agent untuk melakukan earnings management untuk membuat kinerja perusahaan terlihat baik dalam laporan keuangan. Namun, ketika kreditor mengetahui praktik earnings management yang dilakukan oleh perusahaan, kreditor tidak lagi mengapresiasi kinerja keuangan perusahaan tersebut. Hal itu dikarenakan kinerja keuangan perusahaan tersebut bukan dipengaruhi oleh kinerja perusahaan yang sesungguhnya, tetapi juga dipengaruhi oleh kebijakan akuntansi yang digunakan oleh manajemen.

\section{SARAN}

Dari hasil penelitian yang telah dilakukan adapun saran-saran yang dapat diberikan yaitu sebagai berikut. Pertama, pada penelitian ini setiap variabelnya hanya menggunakan satu model perhitungan, seperti pertama, pada perhitungan kinerja perusahaan, digunakan Return on Equity (ROE), diharapkan pada penelitian selanjutnya dapat menambah/menggunakan proksi lain seperti Return On Asset (ROA) atau Return on Investment (ROI). (2) pada perhitungan earnings management hanya menggunakan satu model yaitu Modified Jones model, diharapkan pada penelitian selanjutnya dapat membandingkannya dengan model lain seperti the Healy Model, the De Angelo model. (3) dalam perhitungan biaya utang, digunakan cara beban bunga dibagi dengan rata-rata utang. Pada penelitian selanjutnya dapat menggunakan cara lain untuk perhitungan biaya utang, misalnya menggunakan Bond Yieldspread. Kedua, penelitian ini hanya menggunakan data sekunder, maka diharapkan untuk peneliti selanjutnya dapat melakukan penelitian dengan data yang lebih beragam, dengan jumlah variabel yang lebih banyak dan lebih bervariasi.

\section{DAFTAR PUSTAKA}

Admadianto, H.N. (2015). Tinjauan Empiris Hubungan Manajemen Laba terhadap Cost of Capital pada Perusahaan yang Terdaftar di Indeks JII dan LQ 45. Seminar Nasional dan The 3rd Call for Syariah Paper, Universitas Muhammadiyah Surakarta.

Amalina, N. (2017). Analisis Pengaruh Manajemen Laba Kinerja Perusahaan Kualitas Audit dan Investment Opportunity Set terhadap Biaya Ekuitas. Tesis. Fakultas Pasca Sarjana Universitas Muhammadiyah Surakarta. Surakarta.

Amperaningrum, I. \& Sari, I. K. (2013). Pengaruh Good Corporate Governance, Leverage, dan Kinerja Keuangan terhadap Manajemen Laba (Studi Kasus pada Perusahaan Perbankan yang Terdaftar di Bursa Efek Indonesia). Jurnal Proceeding PESAT (Psikologi, Ekonomi, Sastra, Arsitektur \& Teknik Sipil), 5, 294-302.

Andayani, T. D. (2010). Telaah Tentang Manajemen Laba. Jurnal Akuntansi, 6(2), 88-99.

Anderson, R.C., Mansi, S.A. and Reeb, D. M.. (2003). Board characteristics, accounting report integrity, and the cost of debt. Diakses, 17 April 2017, http://papers.ssrn.com/sol3/papers.cfm?abstract_id=491883 
Arief, A. (2013). Teori Keagenan (Agency Theory). Diakses, 17 April 2017, http://anggyansyah.blogspot.co.id/2013/01/teori-keagenan-agency-theory.html?m=1

Dechow, P.M., (1994). Accounting Earnings and Cash Flows as Measures of Firm Performance: The Role of Accounting Accruals. Journal of Accounting and Economics $18,3-42$.

Dechow, P.M., Hutton, A.P., \& Sloan, R.G., (1999). An empirical assessment of the residual income valuation model. Journal of Accounting and Economics, 34, 1-34.

Dechow, P.M., Richard, G.S., \& Amy P.S.(1995). Detecting Earnings Management. The Accounting Review, 70(2), 193-225.

Demirkan, S., Radhakrishnan, S., \& Urcan, O. (2011). Discretionary Accruals Quality, Cost of Capital, and Diversification. Journal of Accounting, Auditing and Finance, 1-45.

Dewi, R. P. \& Priyadi, M. P. (2016). Pengaruh Free Cash Flow, Kinerja Keuangan terhadap Earnings Management Dimoderasi Corporate Governance. Jurnal Ilmu dan Riset Akuntansi, 5(2), 1-24.

Fabozzi, F. J. (2007). Bond Markets, Analysis, and Strategies (ed.8). New Jearsey: Prentice Hall.

Fahmi, I. (2012). Analisis Kinerja Keuangan. Bandung: Alfabeta.

Febrininta, C. N. \& Siregar, S. V. (2014). Manajemen Laba Akrual, Manajemen Laba Riil, dan Biaya Modal. Jurnal Akuntansi Multiparadigma, 5(3), 365-379.

Fitriyani. (2014). Pengaruh Manajemen Laba terhadap Biaya Modal Ekuitas (Pada Perusahaan Manufaktur yang Terdaftar di Bursa Efek Indonesia). Skripsi. Fakultas Ekonomi Universitas Widyatama. Bandung.

Francis, J. R., Khurana, I. K., \& Pereira, R. (2005). Disclosure Incentives and Effects on Cost of Capital around the World. The Accounting Review, 80(4), 1125-1162.

Francis, J., LaFond, R., Olsson, P., \& Schipper, K., (2004). Costs of Equity And Earnings Attributes. The Accounting Review, 79, 967-1010.

Francis, J., LaFond, R., Olsson, P., \& Schipper, K., (2005a). The Market Pricing of Accruals Quality. Journal of Accounting and Economics, 39, 295-327.

Francis, J., Maydew, E., Sparks, H., 1999. The role of Big 6 auditors in the credible reporting of accruals. Auditing 18, 17-34.

Francis, J., Nanda, D., \& Olsson, P., (2008). Voluntary Disclosure, Earnings Quality, and Cost of Capital. Journal of Accounting Research, 46, 53-99.

Ge, W. \& J. B. Kim. 2014. Real Earnings Management and the Cost of New Corporate Bonds. Journal of Bussiness Research, 67, 641-647.

Ghozali, I. (2005). Aplikasi Analisis Multivariate dengan Program SPSS edisi ketiga. Semarang: Badan Penerbit Universitas Diponegoro.

Ghozali, I. (2011). Aplikasi Analisis Multivariate dengan Program IBM SPSS 19 edisi kelima. Semarang: Universitas Diponegoro.

Gujarati, D. (1995). Ekonometrika Dasar. Jakarta: Erlangga.

Gujarati, D. N. (2003). Basic econometrics. New York: Mc Graw Hill.

Guna, W. I. \& A. Herawaty. (2010). Pengaruh Mekanisme Good Corporate Governance, Independensi Auditor, Kualitas Audit, dan Faktor Lainnya Terhadap Manajemen Laba. Jurnal Bisnis dan Akuntansi, 12 (1), 53-68.

Gunawan, I. K., Darmawan, N. A. S. \& Purnamawati. I. G. A. (2015). Pengaruh Ukuran Perusahaan, Profitabilitas, dan Leverage terhadap Manajemen Laba pada Perusahaan Manufaktur yang Terdaftar di Bursa Efek Indonesia (BEI). E-journal S1 Ak Universitas Pendidikan Ganesha Jurusan Akuntansi Program S1, 03(01), 1-10.

Harahap, S. S. (2013). Analisis Kritis Atas Laporan Keuangan. Jakarta: Rajawali Pers. Ikatan Akuntan Indonesia. (2012). Standar Akuntansi Keuangan.. Jakarta: Salemba Empat. Ivani, G. (2015). Pengaruh Manipulasi Aktivitas Riil Terhadap Arus Kas Operasi Satu Tahun 
ke Depan. Skripsi, Universitas Atma Jaya Yogyakarta.

Jefriansyah. (2015). Pengaruh Kebijakan Hutang dan Manajemen Laba terhadap Nilai Perusahaan (Studi Empiris pada Perusahaan Manufaktur yang Terdaftar di BEI). Skripsi. Fakultas Ekonomi Universitas Negeri Padang. Padang.

Jensen, M. C. \& Meckling, W. H. (1976). Theory of the Firm: Managerial Behaviour, Agency Cost and Ownership Structure. Journal of Financial Economics, 3(4), 305-360.

Jones, J., (1991). Earnings Management during Import Relief Investigations. Journal of Accounting Research, 29, 193-228.

Kasmir. (2013). Analisis Laporan Keuangan. Jakarta: Rajawali Pers.

Kuncoro, M. (2011). Metode Kuantitatif: Teori dan Aplikasi untuk Bisnis dan Ekonomi. Yogyakarta: UPP STIM YKPN.

Kurnia, N. (2013). Pengaruh Kinerja Perusahaan dan Risiko Sistematis terhadap Return Saham (Studi Empiris pada Perusahaan Property dan Real Estate yang Terdaftar di BEI). Skripsi. Fakultas Ekonomi Universitas Negeri Padang. Padang.

Nikoomaram, H., F. Arabahmadi \& Arabahmadi. A. (2016). The Relationship between earning management and capital structure. International Journal of Finance and Managerial Accounting, 1(1), 51-56.

Nugroho, D. R. (2014). Pengaruh Good Corporate Governance terhadap Biaya Ekuitas dan Biaya Utang (Studi Pada Perusahaan Manufaktur Yang Terdaftar di BEI Tahun 20102012. Skripsi, Universitas Diponegoro.

Pratiwi, A. P. (2015). Tingkat Kinerja Perusahaan Mempengaruhi Manajemen Laba. Kompasiana. Diakses, Juni 2017.

Prevost, A. K., Skousen, C. J. \& Rao, R. P. (2008). Earnings Management and the Cost of Debt. Diakses, 21 April 2017, https://www.researchgate.net/publication/228266825_Earnings_Management_and_the_ Cost_of Debt

Ratnasari, F. (2014). Analisis Pengaruh Kualitas Auditor dan Karakteristik Perusahaan Terhadap Biaya Utang (Cost of Debt). Skripsi, Universitas Diponegoro.

Sawir, A. (2009). Analisa Kinerja Keuangan dan Perencanaan Keuangan Perusahaan. Jakarta: PT. Gramedia Pustaka Utama.

Scott, W. R. (2015). Financial Accounting Theory. Seventh Edition. Canada: Prentice Hall.

Srimindarti, C. (2004). Balanced Scorecard Sebagai Alternatif untuk Mengukur Kinerja. Fokus Ekonomi, 3 (1), 52-64.

Subramanyam, K. R. \& Wild, J. J. (2014). Analisis Laporan Keuangan (Dewi Yanti, Penerjemah.). Jakarta: Salemba Empat.

Sugiyono. (2013). Metode Penelitian Kuantitatif, Kualitatif dan R\&D. Bandung: Alfabeta.

Sugiyono. (2014). Metode Penelitian Kuantitatif Kualitatif dan R\&D. Bandung: Alfabeta.

Sunyoto, D. \& F. E. Susanti. (2015). Manajemen Keuangan untuk Perusahaan. Yogyakarta: Center of Academic Publishing Service.

Sutrisno. (2009). Manajemen Keuanagan Teori, Konsep dan Aplikasi. Yogyakarta: Ekonisia.

Triningtyas, I. A. \& Siregar, S. V. (2014). Pengaruh Kualitas Akrual terhadap Biaya Utang dan Biaya Ekuitas: Studi pada Perusahaan yang Terdaftar di Bursa Efek Indonesia Tahun 2005-2011. Simposium Nasional Akuntansi XVII, Jakarta.

Widarjono, A. (2007). Ekonometrika Teori dan Aplikasi. Yogyakarta: Ekonisia FE UII.

Yuliani, F. (2016). Pengaruh Manajemen Laba Riil dan Manajemen Laba Akrual terhadap Biaya Utang. Skripsi. Sekolah Tinggi Ilmu Ekonomi Indonesia. Jakarta. 